\title{
Polychlorinated dibenzo-p-dioxins, dibenzofurans and polychlorinated biphenyls in New Zealand cetaceans*
}

\author{
Paul. D. Jones ${ }^{1}$, Donald J. Hannah ${ }^{1}$, Simon J. Buckland ${ }^{\text {, Tania Van Maanen }}{ }^{\text {, }}$, \\ Scott V. Leathem ${ }^{1}$. Stephen Dawson ${ }^{2}$, Elisabeth Slooten ${ }^{2}$, Anton van Helden 3 \\ and Michael Donoghue ${ }^{4}$
}

Contacte-mail: JonesP\%AHAdmin@Lincoln.cri.nz

\begin{abstract}
Limited information is available on the concentrations of halogenated aromatic hydrocarbons (HAHs) in cetaceans from the Southern Hemisphere. This paper presents data on blubber concentrations of polychlorinated dibenzo-p-dioxins (PCDDs), polychlorinated dibenzofurans (PCDFs) and polychlorinated biphenyls (PCBs) in Hector's dolphins, dusky dolphins, southern right whale dolphins, blue whales, minke whales, Gray's beaked whales, Cuvier's beaked whales and pygmy right whales stranded in New Zealand. Both HAH concentrations and toxic equivalents (TEQs) are found to be higher in Hector's dolphins, a species with an inshore distribution, than in other odontocetes, which are more oceanic. Baleen whales, which are oceanic and feed at lower trophic levels, present the lowest levels of pollutants, with PCDD and PCDF concentrations usually below detection limits. The PCB profiles of the various species suggest that they are exposed to different PCB sources. Overall, HAH levels detected are lower than those reported for comparable species in the Northern Hemisphere. The relative abundance of low chlorinated PCB congeners in New Zealand cetaceans, as compared to those from northern waters, suggests that the origin of these compounds is mostly atmospheric deposition.
\end{abstract}

KEYWORDS: POLLUTION; SOUTHERN HEMISPHERE; SOUTH PACIFIC; AREA-NEW ZEALAND; HECTOR'S DOLPHIN; DUSKY DOLPHIN; SOUTHERN RIGHT WHALE DOLPHIN; BLUE WHALE; MINKE WHALE; PYGMY RIGHT WHALE; GRAY'S BEAKED WHALE; CUVIER'S BEAKED WHALE

\section{INTRODUCTION}

Limited information is available on the occurrence and distribution of halogenated aromatic hydrocarbons ( $\mathrm{HAH} s$ ) such as polychlorinated dibenzo-p-dioxins (PCDDs), polychlorinated dibenzofurans (PCDFs) and polychlorinated biphenyls (PCBs) in Southern Hemisphere cetaceans (Tanabe et al., 1983). HAHs are known to bioaccumulate and biomagnify, with recent studies linking these compounds to reproductive deficiencies in some wildlife species (Reijnders, 1986; Colborn and Clement, 1992; Giesy et al., 1994) and other adverse biological effects in cetaceans (Béland et al., 1993). Cetaceans have been shown to bioaccumulate high concentrations of some HAHs (Tanabe et al., 1988; Muir and Norstrom, 1991) and are, therefore, at risk from the effects of these contaminants. This ability to accumulate high levels of some HAHs also makes cetaceans potential indicator species for

\footnotetext{
* A version of this paper was originally submitted to the IWC Scientific Committee as SC/46/O12.

${ }^{1}$ ESR.Environmental, Lower Hutr, New Zealand.

2 Department of Zoology, University of Otago, Dunedin. New Zealand.

${ }^{3}$ Museum of New Zealand Te Papa Tongarewa, Wellington. New Zealand.

${ }^{4}$ Department of Conservation, Auckland, New Zealand.
} 
monitoring the contamination of the marine environment (Muir and Norstrom, 1991). We present data on concentrations of HAHs in a number of cetaceans collected around the coast of New Zealand.

\section{MATERIALS AND METHODS}

PCDD, PCDF and PCB congeners were analysed following the methodology of Buckland et al. (1990) and Hannah et al. (1993). ${ }^{13} \mathrm{C}_{12}$ dioxin, furan and PCB congeners were added to each sample, before extraction, to act as surrogate internal standards for the calculation of 'native' congener concentration. Samples were then extracted four times by blending with $30 \mathrm{ml} \mathrm{2:1} \mathrm{acetone:hexane.} \mathrm{Extracts} \mathrm{were} \mathrm{dried} \mathrm{by} \mathrm{passage} \mathrm{through} \mathrm{anhydrous} \mathrm{Na}_{2} \mathrm{SO}_{4}$, concentrated to near dryness and redissolved in $50 \mathrm{ml}$ of hexane. A $5.0 \mathrm{ml}$ portion of the extract was removed for gravimetric lipid determination. The remaining extract, after any sub-sampling, was transferred to a separating funnel and washed eight times with concentrated $\mathrm{H}_{2} \mathrm{SO}_{4}$ followed by three washes with $\mathrm{H}_{2} \mathrm{O}$. The extract was again dried through $\mathrm{Na}_{2} \mathrm{SO}_{4}$ before being chromatographed sequentially on columns of $\mathrm{H}_{2} \mathrm{SO}_{4} /$ silica: $\mathrm{NaOH} /$ silica, $\mathrm{Al}_{2} \mathrm{O}_{3}$, and Carbopac $\mathrm{C}$ dispersed on Celite. PCB congeners pass through the Carbopac column while PCDDs and PCDFs are retained and eluted into a separate fraction. The PCB fraction was chromatographed on Florisil to isolate the three non-ortho substituted congeners (Lazar et al., 1992). All analytes were determined by HRGC/HRMS on a VG 70S mass spectrometer.

Toxic Equivalency Factors (TEFs) express the potency of individual HAH congeners relative to 2,3,7,8-TCDD, the most potent $\mathrm{HAH}$ congener. The concentration of each congener in the extracts was multiplied by its TEF (Ahlborg et al., 1988; 1994) and the sum of these values gives the total toxic equivalents (TEQs) concentration in the extract.

\section{QUALITY ASSURANCE}

The dioxin laboratory maintains World Health Organisation (WHO) and TELARC (Testing Laboratory Registration Council of New Zealand) accreditation for the analysis of PCDD, PCDF and PCB congeners in a variety of environmental matrices. Laboratory blanks were run with each batch of samples. All data analysis was subject to strict quality assurance procedures as previously described (Buckland et al., 1990).

\section{SAMPLES AND SPECIES}

All samples analysed in this study were obtained from dead stranded cetaceans.

Hector's dolphin (Cephalorhynchus hectori) is an inshore dolphin with a small home range feeding on a variety of fish species (Slooten and Dawson, 1988). In contrast, the other odontocetes studied, i.e. the common dolphin (Delphinus delphis), the dusky dolphin (Lagenorhynchus obscurus), the southern right whale dolphin (Lissodelphis peronii), Gray's beaked whale (Mesoplodon gravi) and Cuvier's beaked whale (Ziphius cavirostris) are open ocean species and are believed to feed on a variety of fish, squid and crustacea (e.g. see summary in Martin, 1990).

All of the mysticetes (baleen whales) examined are open ocean filter feeders. The minke (Balaenoptera acutorostrata) and blue whale (B. musculus) feed largely on krill (e.g. Kawamura, 1994) and the rare pygmy right whale (Caperea marginata), the smallest of the baleen whales, appears to feed mainly on copepods (Best et al., 1992).

Numbers of specimens and available biometric data for the individuals analysed are provided in Table 1. As these specimens were collected by several people over several years 
not all biometric data are available, in particular data on age and other biological information was often lacking. As contaminant concentrations in cetaceans are known to vary with age and sex, the data are presented and discussed primarily as 'group' averages. Groups are defined in Table 1. Individual data are given in Appendix 1.

Table 1

Biometric data for cetacean specimens analysed.

\begin{tabular}{llll}
\hline Sample type & Common name & Age & Sex \\
\hline Oceanic dolphiris & Common dolphin & Mature & Male \\
& Common dolphin & Male \\
& Dusky dolphin & Male \\
& S.right whale dolphin & Mature & Male \\
Baleen whales & Minke whale & lyr & Female \\
& Blue whale & Mature & Male \\
& Pygmy right whale & Mature & Female \\
& Pygmy right whale & Sub-adult & Female \\
& Gray's beaked whale & $<1$ yr & Male \\
Beaked whales & Gray's beaked whale & $<1$ yr & Female \\
& Gray's beaked whale & Mature & Female \\
& Cuvier's beaked whale & Mature & Male \\
& Gray's beaked whale & Mature & Male \\
& Gray's beaked whale & Mature & Female \\
& Hector's dolphin & Mature & Male \\
& Hector's dolphin & Mature & Male \\
& Hector's dolphin & lyr & Male \\
& Hector's dolphin & lyr & Male \\
& Hector's dolphin & $10 y r s$ & Female \\
& Hector's dolphin & lyrs & Female \\
\hline
\end{tabular}

\section{RESULTS AND DISCUSSION}

PCB congeners were detectable in all samples analysed. The 'group'-average sum of PCB congener concentrations was lowest $(<50 \mathrm{ng} / \mathrm{g}$ wet weight) in the open ocean mysticetes (minke, blue and pygmy right whales), intermediate (100 to $500 \mathrm{ng} / \mathrm{g}$ wet weight) in open ocean odontocetes (beaked whales and open ocean dolphins) and highest (750 to $>1,000 \mathrm{ng} / \mathrm{g}$ wet weight) in the inshore Hector's dolphin (Table 2). PCB profiles from the open ocean baleen and beaked whale species show an abundance of lower chlorinated PCB congeners relative to the inshore Hector's dolphin (Fig. 1). The principle source of these congeners is believed to be atmospheric deposition. However, the difference is much less apparent when comparing inshore and offshore dolphins.

PCDD and PCDF congeners were only commonly detected in the inshore feeding Hector's dolphin (Table 2). The concentrations of almost all PCDD and PCDF congeners were below detection limits in the baleen whale species. In open ocean dolphins and beaked whales hepta- and octa-chlorinated PCDD and PCDF congeners were the most commonly detected congeners.

Toxic Equivalency Factors (TEFs) can be used to calculate the biological potency of HAH mixtures relative to 2,3,7,8-TCDD, the most potent HAH congener (Ahlborg et al., 1988; 1994). Using this method, the total concentration of TCDD-Equivalents (TEQs) were 
calculated for the different cetacean groups (Table 2). TEQs were lowest in the baleen whales, higher in the open ocean odontocetes and highest in the inshore Hector's dolphin. By calculating the TEQ contributed by specific compounds analysed it is possible to assess their relative toxicological significance (Fig. 2). The contribution of PCDD and PCDF to the TEQ

Table 2

Mean chlorinated hydrocarbon congener concentrations in blubber of different groups of southern ocean cetaceans (PCBs in ng/g wet weight; PCDD and PCDF in pg/g wet weight). Where values less than the detection limit occurred, one half of that detection limit was used to calculate the mean. TEFs from Ahlborg et al., 1988; A hlborg et al, 1994. na = not analysed. nd = not detected. * PCDD and PCDF data from Buckland et al., 1990.

\begin{tabular}{|c|c|c|c|c|c|c|}
\hline Analyte & TEF & $\begin{array}{l}\text { Pygmy } \\
\text { right }\end{array}$ & $\begin{array}{l}\text { Baleen } \\
\text { whales }\end{array}$ & $\begin{array}{l}\text { Oceanic } \\
\text { dolphins }\end{array}$ & $\begin{array}{l}\text { Beaked } \\
\text { whales }\end{array}$ & $\begin{array}{l}\text { Hector's } \\
\text { dolphin* }\end{array}$ \\
\hline PCB $\# 28$ & 0 & 0.25 & 0.03 & 0.93 & 0.95 & 3.78 \\
\hline PCB \#52 & 0 & 0.34 & 1.30 & 14.5 & 4.90 & 9.93 \\
\hline PCB \#77 & 0.0005 & 0.005 & 0.002 & 0.08 & 0.06 & 0.09 \\
\hline PCB \#101 & 0 & 0.42 & 1.87 & 60.1 & 19.7 & 32.5 \\
\hline PCB $\# 99$ & 0 & 0.23 & 1.41 & 44.0 & 23.3 & 56.9 \\
\hline PCB \#118 & 0.0001 & 0.20 & 0.79 & 37.5 & 14.7 & 56.1 \\
\hline PCB \#105 & 0.0001 & 0.11 & 0.23 & 10.9 & 4.25 & 28.7 \\
\hline PCB \#126 & 0.1 & 0.003 & 0.01 & 0.06 & 0.08 & 0.43 \\
\hline PCB \#153 & 0 & 0.58 & 2.89 & 267 & 64.5 & 330 \\
\hline PCB \#138 & 0 & 0.85 & 2.64 & 232 & 48.7 & 240 \\
\hline PCB \#169 & 0.01 & 0.002 & 0.02 & 0.14 & 0.07 & 0.09 \\
\hline PCB \#187 & 0 & 0.28 & 0.80 & 46.8 & 24.8 & 77.7 \\
\hline PCB \#183 & 0 & 0.02 & 0.23 & 16.3 & 6.97 & 29.4 \\
\hline PCB \#180 & 0.00001 & 0.14 & 0.77 & 68.1 & 21.1 & 86.2 \\
\hline PCB \#170 & 0.0001 & 0.17 & 0.34 & 22.6 & 13.7 & 64.3 \\
\hline PCB \#202 & 0 & 0.001 & 0.03 & 5.46 & 1.43 & 1.6 \\
\hline PCB \#194 & 0 & 0.001 & 0.02 & 8.50 & 1.64 & na \\
\hline Congener sum (ng/g) & & 3.61 & 12.9 & 833 & 251 & 1,018 \\
\hline $2,3,7,8-\mathrm{TeF}$ & 0.1 & 0.06 & 0.10 & 0.10 & 0.15 & 9.12 \\
\hline non-2,3,7,8-TeF & 0 & 0.11 & 0.18 & 3.70 & 1.30 & nd \\
\hline $2,3,7,8-\mathrm{TeD}$ & 1.0 & 0.10 & 0.08 & 0.10 & 0.06 & 7.83 \\
\hline non-2,3,7,8-TeD & 0 & 0.18 & 0.08 & 0.10 & 0.10 & nd \\
\hline $1,2,3,7,8-\mathrm{PeF}$ & 0.05 & 0.06 & 0.05 & 0.10 & 0.12 & 0.77 \\
\hline $2,3,4,7,8-\mathrm{PeF}$ & 0.5 & 0.13 & 0.10 & 0.02 & 0.22 & 24.6 \\
\hline non-2,3,7,8-PeF & 0 & 0.18 & 0.20 & 6.44 & 1.79 & nd \\
\hline $1,2,3,7,8-\mathrm{PeD}$ & 0.5 & 0.13 & 0.10 & 0.10 & 0.09 & 9.08 \\
\hline non-2,3,7,8-PeD & 0 & 0.23 & 0.13 & 0.15 & 0.09 & nd \\
\hline $1,2,3,4,7,8-\mathrm{H} \times \mathrm{F}$ & 0.1 & 0.13 & 0.08 & 0.10 & 0.10 & nd \\
\hline $1,2,3,6,7,8-H x F$ & 0.1 & 0.10 & 0.12 & 0.10 & 0.09 & 0.56 \\
\hline $2,3,4,6,7,8-\mathrm{HxF}$ & 0.1 & 0.13 & 0.12 & 0.10 & 0.17 & 0.51 \\
\hline $1,2,3,7,8,9-\mathrm{HxF}$ & 0.1 & 0.18 & 0.15 & 0.10 & 0.06 & 0.27 \\
\hline non-2,3,7,8-HXF & 0 & 0.20 & 0.20 & 2.96 & 0.82 & nd \\
\hline $1,2,3,4,7,8-\mathrm{HpD}$ & 0.1 & 0.15 & 0.12 & 0.04 & 0.07 & nd \\
\hline $1,2,3,6,7,8-\mathrm{H} \mathrm{pD}$ & 0.1 & 0.15 & 0.17 & 0.04 & 0.15 & 2.83 \\
\hline $1,2,3,7,8,9-\mathrm{HpD}$ & 0.1 & 0.18 & 0.12 & 0.04 & 0.08 & 0.23 \\
\hline non-2,3,7,8-HpD & 0 & 0.30 & 0.20 & 0.10 & 0.15 & nd \\
\hline $1,2,3,4,6,7,8-\mathrm{HpF}$ & 0.01 & 0.28 & 0.43 & 0.05 & 0.19 & 0.30 \\
\hline $1,2,3,4,7,8,9-\mathrm{HpF}$ & 0.01 & 0.18 & 0.15 & 0.04 & 0.05 & 0.08 \\
\hline non- $2,3,7,8-\mathrm{HpF}$ & 0 & 0.43 & 0.85 & 0.20 & 0.10 & nd \\
\hline $1,2,3,4,6,7,8-\mathrm{HpD}$ & 0.01 & 0.65 & 0.98 & 0.15 & 0.53 & 3.15 \\
\hline non-2,3,7,8-HpD & 0 & 0.68 & 0.76 & 0.50 & 0.27 & nd \\
\hline OCDF & 0.001 & 0.52 & 2.33 & 0.15 & 0.26 & 1.54 \\
\hline OCDD & 0.001 & 2.75 & 10.2 & 0.50 & 3.91 & 12.5 \\
\hline TEQ (pg/g) & & 0.77 & 1.9 & 15.7 & 12.5 & 81.4 \\
\hline
\end{tabular}




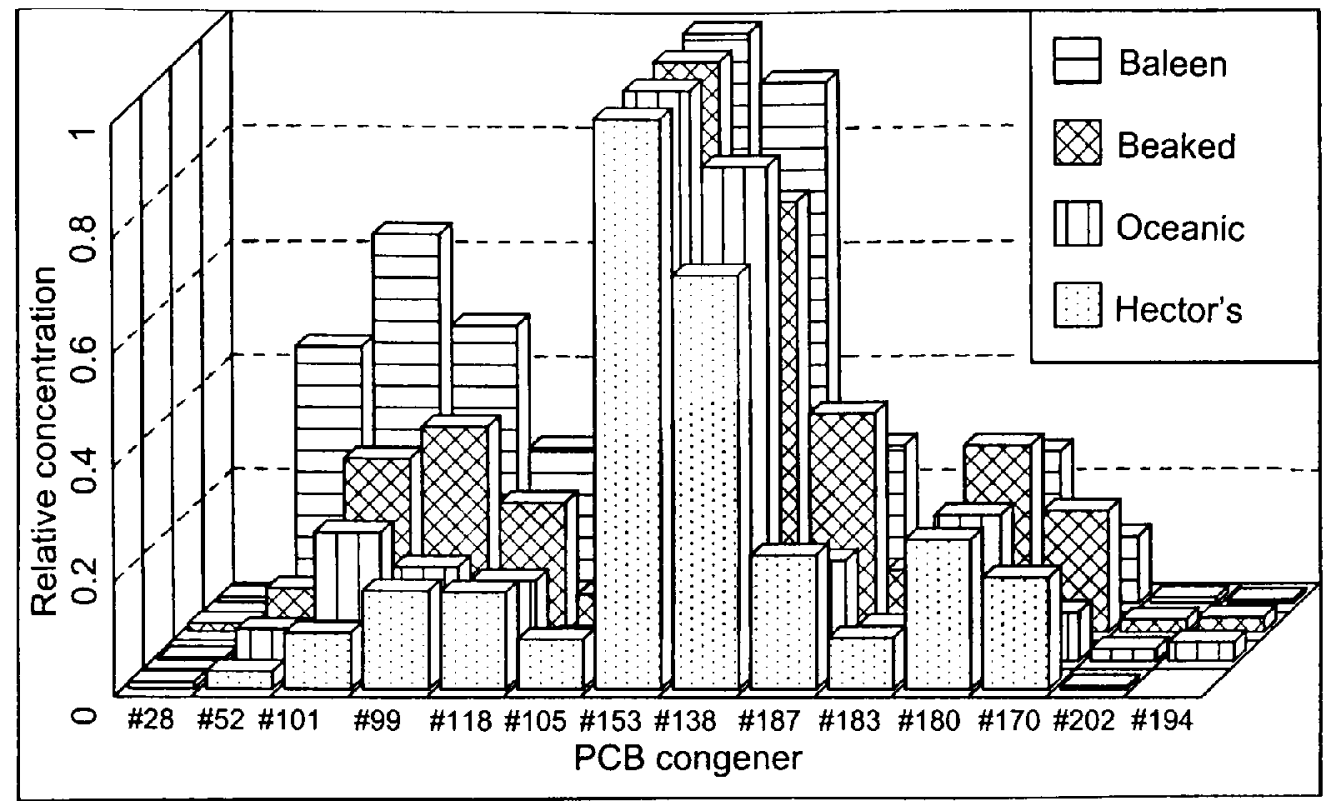

Fig. 1. PCB congener profiles for different cetacean groups. Baleen = baleen whales, Beaked=beaked whales, Oceanic = oceanic dolphins, Hector's = Hector's dolphin. Concentrations are expressed relative to CB 153.

was less than $20 \%$ of the total TEQ in all open ocean groups except the pygmy right whale. The higher contribution of PCDD and PCDF in this group can be explained by the low levels of TEQs found $(<1 \mathrm{pg} / \mathrm{g}$ wet weight) which resulted in a high number of 'non-detect' values. For calculation of TEQs, half the detection limit is taken for these non-detect values. Therefore, at low contaminant levels TEQ can be overestimated because of the high number of non-detect values. The levels of TEQs detected in Hector's dolphin are higher than in the other groups and the contribution of PCDD and PCDF to total TEQs is also greater.

The correlation between average 'group' PCB congener sums and TEQs in different cetacean species (Fig. 3) supports the hypothesis that these groups are exposed to different PCB sources. Any single source of HAHs will have a relatively fixed profile and therefore a fixed potency expressed as TEQ per mass of PCB. As the ratio of TEQ accumulated per mass of PCB is higher in Hector's dolphin than in the open ocean species, this suggests that this species is exposed to an HAH source of higher potency. This is also evident from the higher contribution of PCDD and PCDF to total TEQ in Hector's dolphin, previously mentioned.

A cluster analysis (Fig. 4) was performed using the PCB congener data only. PCDD and PCDF congener concentrations were not used in this statistical analysis due to the high number of non-detect values for these congeners in the open ocean cetaceans. This analysis demonstrated the similarity among the individuals of the various cetacean groups, particularly for Hector's dolphin and Gray's beaked whale. Interestingly, the Gray's beaked whale cluster is quite distinct from the open ocean dolphin cluster which also includes the single Cuvier's beaked whale. Little information is available on the dietary habits of Gray's beaked whale. However, this analysis may indicate a diet distinct from the open ocean dolphins and more similar to that of Hector's dolphin (e.g. Slooten and Dawson, 1988). Cuvier's beaked whale appears to be a catholic feeder on deep sea-fish and squid (Nishiwaki and Oguro, 1972). 


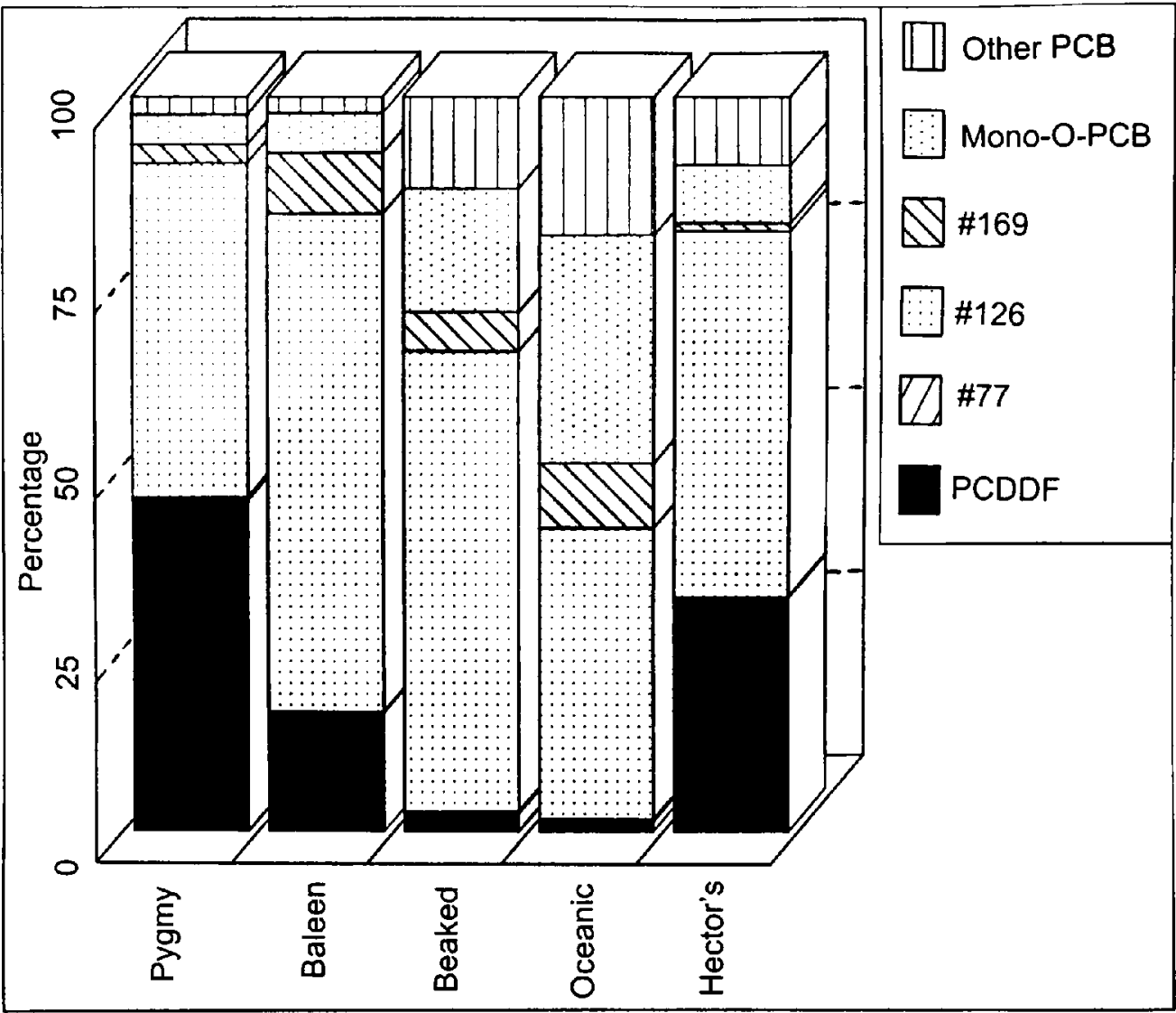

Fig. 2. Percent contribution of HAH classes and individual PCB congeners to total 2,3,7,8-TCDD toxic equivalents (TEQ).

\section{CONCLUSIONS}

The relative concentrations of chlorinated hydrocarbons in the different species examined indicates that their accumulation is related to both food habit and proximity to the coast. For example, total PCB concentrations are greater in beaked whales than in baleen whales - both are open ocean species but the latter feed lower in the food web. Higher concentrations of PCBs in Hector's dolphin as compared to common dolphins indicate higher exposure in inshore species.

Concentrations of PCBs detected in common dolphins, beaked whales and baleen whales in New Zealand are lower than those reported for similar species in the Northern Hemisphere (Table 3). This observation is to be expected considering the relative remoteness of the area from the major sources of PCB contamination that are mainly located in the Northern Hemisphere.

PCB profiles from open ocean marine mammals show an abundance of lower chlorinated PCB congeners. This abundance is most noticeable in the baleen whales which feed near the bottom of the food chain. However, the pattern is still detectable in other open ocean species. The abundance of the lower chlorinated, therefore more volatile, PCBs suggests that the principle source of these congeners is atmospheric deposition. 


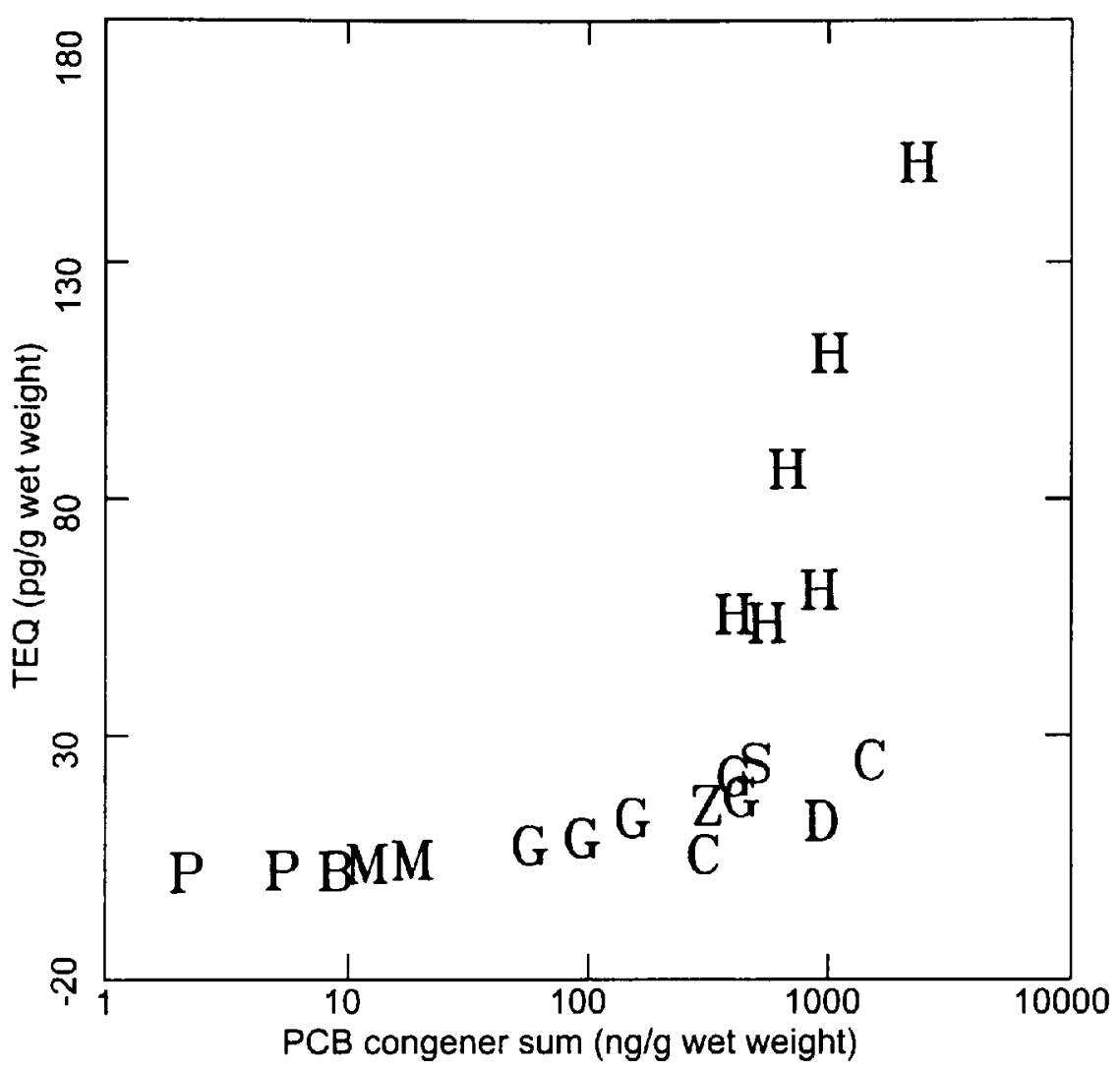

Fig. 3. Concentration of 2,3,7,8-TCDD equivalents as a function of the sum of PCB congeners for southern ocean cetaceans. $\mathrm{H}=$ Hector's dolphin, $\mathrm{C}=$ common dolphin, $\mathrm{D}=$ dusky dolphin, $\mathrm{S}=$ southerm right whale dolphin, $\mathrm{G}=$ Gray's beaked whale, $\mathrm{M}=$ minke whale, $\mathrm{B}=$ southem blue whale, $\mathrm{P}=$ pygmy right whale, $Z=$ Cuvier's beaked whale.

With the exception of the Hector's dolphin, PCDD and PCDF did not contribute a significant level of TEQs. In all the southern ocean cetaceans analysed to date PCBs contribute the major portion of TEQ calculated using the TEF values of Ahlborg $e t$ al. (1994). This situation may arise due to the ability of cetaceans to metabolise PCDD and PCDF congeners (Muir and Norstrom, 1991; Norstrom et al., 1994) but, mostly, because of the limited atmospheric transport and deposition of these HAHs into the southern oceans.

\section{ACKNOWLEDGEMENTS}

The authors wish to express their thanks to the numerous Department of Conservation field officers who provided samples for this research. This research was funded by contributions from ESR:Environmental, the Department of Conservation and the Foundation for Research Science and Technology. 


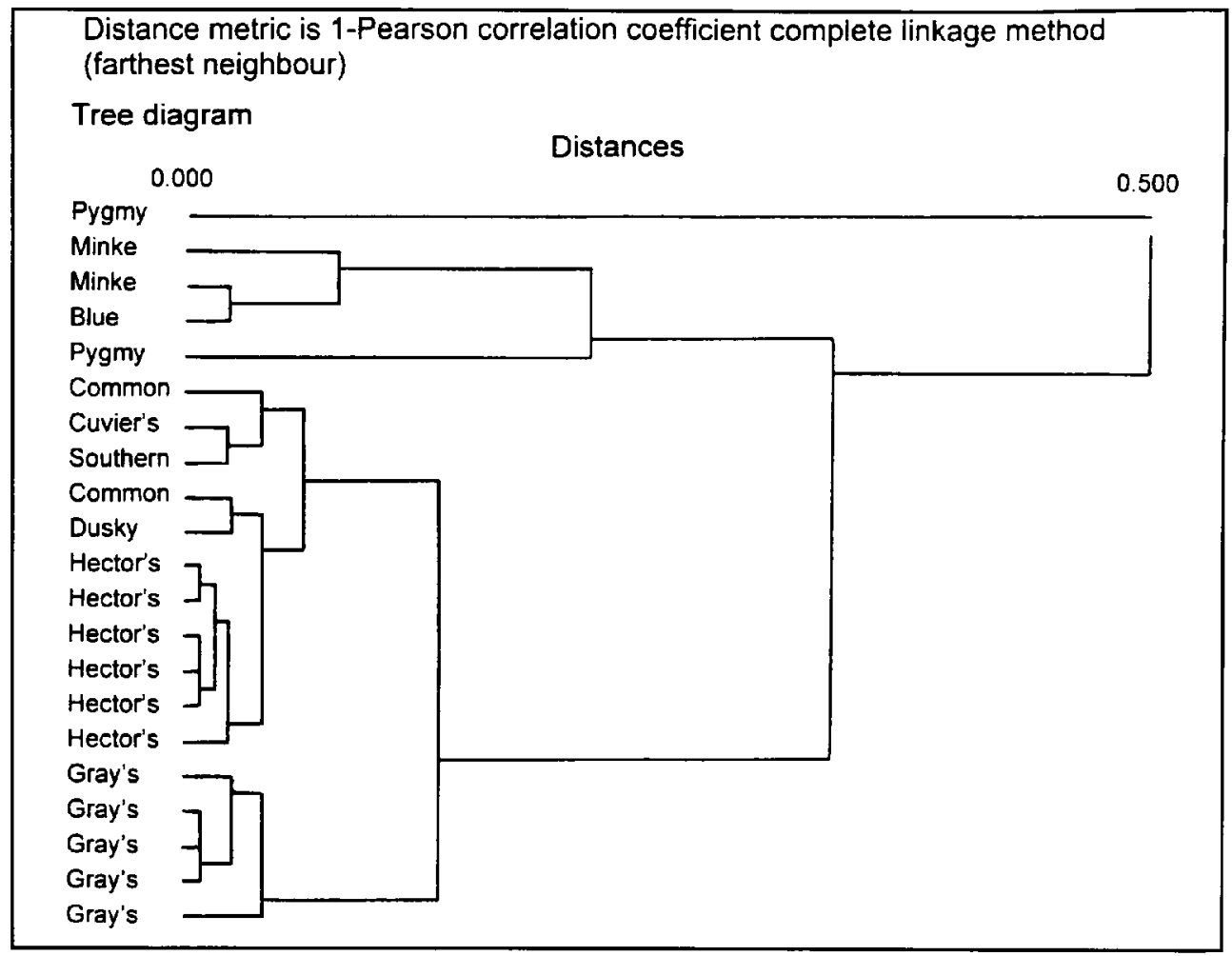

Fig. 4. Cluster analysis of Southern ocean cetaceans using PCB congener profiles. Hectors = Hector's dolphin, Pygmy = pygmy right whale, Minke $=$ minke whale, Blue $=$ blue whale, Grays = Gray's beaked whale, Common = common dolphin, Dusky=dusky dolphin, Cuviers = Cuvier's beaked whale, Southern $=$ southern right whale dolphin.

Table 3

Comparison of total PCB concentrations in cetaceans.

\begin{tabular}{|c|c|c|c|}
\hline Species & Location & PCBs $(\mu g / g)$ & Referencc \\
\hline Bottlenose dolphin & South Africa & 13.8 & Cockroft et al. 1989 \\
\hline Dall's porpoise & North Pacific & 8.6 & Tanabe et al., 1983 \\
\hline White-sided dolphin & Japan & 37.6 & Tanabe et al., 1983 \\
\hline Bottlenose dolphin & East USA & 81.4 & Kuehl et al., 1991 \\
\hline Common dolphin & East USA & 36.5 & Kuehl et al., 1991 \\
\hline White-sided dolphin & Fast USA & 50.1 & Kuehl et al., 1991 \\
\hline Harbour porpoise & UK & 55.5 & Morris et al., 1989 \\
\hline Dusky dolphin & South of NZ & 1.4 & Tanabe et al., 1983 \\
\hline Baleen whales & $\mathrm{NZ}$ & $<0.05^{*}$ & This study \\
\hline Minke whales & West USA & 3.3 & Varanasi et al., 1993 \\
\hline Beaked whales & $\mathrm{NZ}$ & $0.1-0.5^{*}$ & This study \\
\hline Baird's beaked whales & Japan & 3.0 & Subramanian et al., 1988 \\
\hline Common dolphin & $\mathrm{NZ}$ & $0.75->1.0^{*}$ & This study \\
\hline Hector's dolphin & $\mathrm{NZ}$ & $0.4-4.5^{*}$ & This study \\
\hline
\end{tabular}

*Measured as the sum of 16 predominant and biologically active congeners. 


\section{REFERENCES}

Ahlborg, U.G., Hakansson, H., Waern, F. and Hanberg, A. 1988. Nordisk dioxinriskbedomning. Rapport franm en nordisk expertgrupp. Nordiska Ministerradet, Miljororapport. 1988. [In Norwegian]

Ahlborg, U.G., Becking, G.C., Bimbaum, L.S., Brouwer, A., Derks, H.J.G.M., Feeley, M., Golor, G., Hanberg, A., Larsen, J.C., Liem, A.K.D., Safe, S.H., Schlatter, C., Waem, F., Younes, M. and Yrjanheikki, E. 1994. Toxic Equivalency factors for dioxin-like PCBs. Chemosphere 28:1049-67.

Béland, P., de Guise, S.. Girard, C., Lagacé, A., Martineau, D., Michaud, R., Muir, D.C.G., Norstrom, R.J., Pelletier, E., Ray, S. and Shugart, L.R. 1993. Toxic compounds and health and reproductive effects in St Lawrence beluga whales. $J$. Gt Lakes Res. 19(4):766-75.

Best, P.B., Sekiguchi, K. and Kaczmaruk, B.Z. 1992. New information on the feeding habits and Baleen morphology of the pygmy right whale Caperea marginata. Mar. Mammal Sci. 8(3):288-93.

Buckland, S.J., Hannah, D.J., Taucher, J.A., Slooten, E. and Dawson, S. 1990. Polychlorinated dibenzo-p-dioxins and dibenzofurans in New Zealand's Hector's dolphin. Chemosphere 20(7-9): $1035-+2$

Cockcroft, V.G., De Kock, A.C., Lord, D.A. and Ross, G.J.B. 1989. Organochlorines in bottlenose dolphins, Tursiops truncatus, from the east coast of South Africa. S. Afr. J. Mar. Sci. 8:207-17.

Colborn. T. and Clement, C. 1992. Consensus statement: statement from the work session on chemically induced alterations in sexual development: the wildlife/human connection. p. 8. In: T. Colborn and C. Clement (eds.) Chemically Induced Alterations in Sexual and Functional Development: the Wildife Connection. Princeton Scientific Publishing, Princeton, New Jersey.

Giesy, J.P., Ludwig, J.P. and Tillitt, D.E. 1994. Dioxins, dibenzofurans, PCBs and colonial, fish-eating water birds. pp. 249-307. In: A. Schecter (ed.) Dioxins and Health. Plenum Press, New York.

Hannah, D.J., Jones, P.D., Buckland, S.J., van Maanen, T., Leathem, S.V., van Helden, A. and Donoghue, M. 1993. Planar chlorinated hydrocarbons in southem ocean marine mammals. Organohalogen Compounds 12:333-5.

Kawamura, A. 1994. A review on the feeding condition of southern baleen whales. Rep. int. Whal. Commn 44:261-72.

Kuehl, D.W., Haebler, R. and Potter, C. 1991. Chemical residues in dolphins from the US Atlantic coast including Atlantic bottlenose obtained during the 1987-88 mass mortality. Chemosphere 22(11):1071-84.

Lazar, R., Edwards, R.C., Metcalfe, C.D., Metcalfe, T.L., Gobas, F.A.P.C. and Haffner, G.D. 1992. A simple, novel method for the quantitative analysis of coplanar (non-ortho substituted) polychlorinated biphenyls in environmental samples. Chemosphere 25:493-504

Martin, A.R. (ed.). 1990. Whales and Dolphins. Salamander Books, London, New York. 192pp.

Morris, R.J., Law, R.J., Allchin, C.R., Kelly, C.A. and Fileman, C.F. 1989. Metals and organochlorines in dolphins and porpoises of Cardigan Bay, West Wales. Mar. Pollut. Bull. 20(10):512-23.

Muir, D.C.G. and Norstrom, R.J. 1991. Marine mammals as indicators of environmental contamination by PCBs and dioxins/furans. Tech. Rep. Can. Fish. Aquatic Sci 1774:820-6. [Paper presented at the 17th Annual Aquatic Toxicity Workshop, Vancouver, November 1990].

Nishiwaki, M. and Oguro, N. 1972. Catch of the Cuvier's beaked whales off Japan in recent years. Sci. Rep. Whales Res. Inst., Tokyo 24:35-41.

Norstrom, R.J., Muir, D.C.G., Ford, C.A., Simon, M., Macdonald, C.R. and Béland, P. 1994. Indications of P450 monooxygenase activities in beluga (Delphinapterus leucas) and narwhal (Monodon monoceros) from patterns of PCB, PCDD and PCDF accumulation. Mar. Environ. Res. 34(1-4):267-72.

Reijnders, P.J.H. 1986. Reproductive failure in common seals feeding on fish from polluted coastal waters. Nature, Lond. 324:456-7.

Slooten, E. and Dawson, S.M. 1988. Studies on Hector's dolphin, Cephalorhynchus hectori: a progress report. Rep. int. Whal. Commn (special issue 9):325-38.

Subramanian, A., Tanabe, S. and Tatsukawa, R. 1988. Estimating some biological parameters of Baird's beaked whales using PCBs and DDE as tracers. Mar. Pollut. Bull. 19(6):284-7.

Tanabe, S., Mori, T. and Tatsukawa, R. 1983. Global pollution of marine mammals by PCBs, DDTs and HCHs (BHCS). Chemosphere 12:1269-75.

Tanabe, S., Watanabe, S., Kan, H. and Tatsukawa, R. 1988. Capacity and mode of PCB metabolism in small cetaceans. Mar. Mammal Sci. 4(2):103-24.

Varanasi, U., Stein, J.E., Tilbury, K.L., Brown, D.W., Meador, J.P., Krahn, M.M. and Chan, S.-L. 1993. Contaminant monitoring for NMFS Marine Mammal Health and Stranding Response Program. pp. 516-2530. In: O. Magoon, W.S. Wilson, H. Converse and L.T. Tobin (eds.) Symposium on Coastal and Ocean Management. Vol. 3. Coastal Zone '93. American Society of Civil Engineers, New York, New York. [Proceedings of the Eighth Symposium on Coastal and Ocean Management, New Orleans, Louisiana, 19-23 July, 1993] . 
g $\circ$ กี่ ๙ุ o. $\pm$

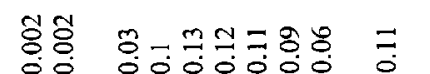
$\stackrel{\infty}{\sim}$ $\infty$

กิ 용

里

$\stackrel{\infty}{\sim}$

웅응

文 山 $\approx$ 응용

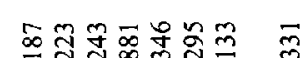

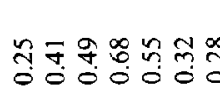

?ำ

- non

\section{$\infty$}

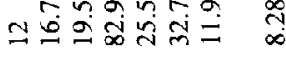

กับ

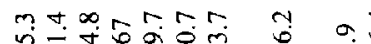
तกำ영

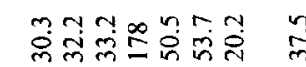

$+2 \pi$

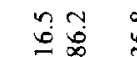

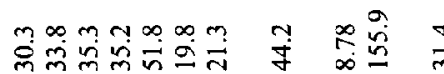

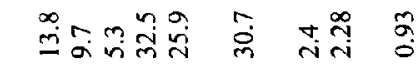

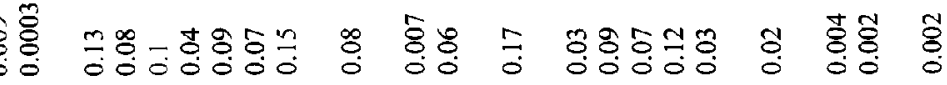

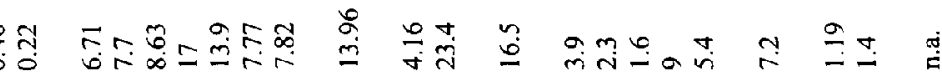

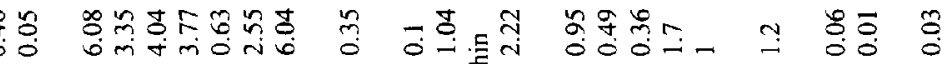

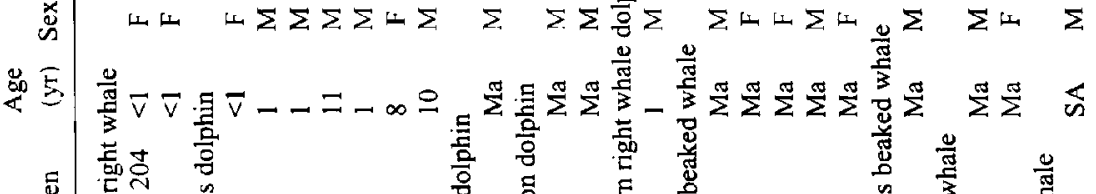
资

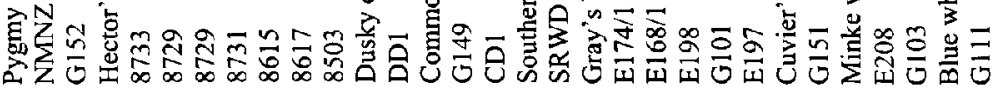




\section{APPENDIX 1b}

Concentrations of PCDD and PCDF congeners in individual marine mammal blubber samples. Concentrations are $\mathrm{pg} / \mathrm{g}$ wet weight. n.a. $=$ not analysed. Values in italics are less than the method detection limit, the values provided are half of the method detection limit. Data for specimens $8733,8729,8731,8615,8617$ and 8503 are from Buckland et al. 1990.

\begin{tabular}{|c|c|c|c|c|c|c|c|c|c|c|c|}
\hline & \multicolumn{11}{|l|}{ NMNZ } \\
\hline & 204 & G152 & 8733 & 8729 & 8731 & 8615 & 8617 & 8503 & DD1 & Gl49 & $\mathrm{CDl}$ \\
\hline $2,3,7,8-\mathrm{TeF}$ & 0.1 & 0.025 & 15.4 & 12.6 & 1.6 & 6.7 & 7.1 & 11.3 & n.a. & 0.1 & n.a. \\
\hline non-2,3,7,8-TeF & 0.2 & 0.025 & n.a. & n.a. & n.a. & n.a. & n.a. & n.a. & n.a. & 3.7 & n.a \\
\hline $2,3,7,8-\mathrm{TeD}$ & 0.15 & 0.05 & 6.2 & 8.5 & 11 & 10.4 & 4 & 6.9 & n.a. & 0.1 & n.a. \\
\hline non- $2,3,7,8-\mathrm{TeD}$ & 0.3 & 0.05 & n.a. & n.a. & n.a. & n.a. & n.a. & n.a. & n.a. & 0.1 & n.a. \\
\hline $1.2 .3 .7,8-\mathrm{PeF}$ & 0.1 & 0.025 & 1.1 & 1.4 & 0.2 & 1.1 & 0.1 & 0.7 & n.a. & 0.1 & n.a. \\
\hline 2.3.4.7,8-PeF & 0.1 & 0.15 & 15.6 & 31.1 & 43.9 & 37.5 & 6.1 & 13.2 & n.a. & 0.02 & n.a. \\
\hline non-2,3,7,8-PeF & 0.2 & 0.15 & n.a. & n.a. & n.a. & n.a. & n.a. & n.a. & n.a. & 6.44 & n.a. \\
\hline $1,2,3,7,8-\mathrm{PeD}$ & 0.15 & 0.1 & 7.9 & 11.7 & 8.1 & 13.4 & 5.5 & 7.9 & n.a. & 0.1 & n.a. \\
\hline non-2,3,7,8-PeD & 0.35 & 0.1 & n.a. & n.a. & n.a. & n.a. & n.a. & n.a. & n.a. & 0.15 & n.a. \\
\hline $1,2,3,4,7,8-\mathrm{HxF}$ & 0.15 & 0.1 & n.a. & n.a. & n.a. & n.a. & n.a. & n.a. & n.a. & 0.1 & n.a. \\
\hline $1.2 .3 .6 .7 .8-\mathrm{HxF}$ & 0.15 & 0.05 & 0.9 & 0.95 & 0.05 & 0.65 & 0.25 & 0.55 & n.a. & 0.1 & n.a. \\
\hline $2,3,4,6,7,8-\mathrm{HxF}$ & 0.15 & 0.1 & 0.6 & 0.8 & 0.3 & 0.9 & 0.15 & 0.3 & n.a. & 0.1 & n.a. \\
\hline $1,2,3.7,8,9-\mathrm{HxF}$ & 0.25 & 0.1 & 0.1 & 0.35 & 0.05 & 0.25 & 0.3 & 0.55 & n.a. & 0.1 & n.a. \\
\hline non-2,3,7,8-HxF & 0.3 & 0.1 & n.a. & n.a. & n.a. & n.a. & n.a. & n.a. & n.a. & 2.96 & n.a \\
\hline $1,2,3,4.7,8-\mathrm{HxD}$ & 0.2 & 0.1 & n.a. & n.a. & n.a. & n.a. & n.a. & n.a. & n.a. & 0.035 & n.a. \\
\hline $1,2,3,6,7,8-\mathrm{HxD}$ & 0.2 & 0.1 & 4.3 & 4.6 & 0.4 & 5.3 & 0.5 & 1.9 & n.a. & 0.04 & n.a. \\
\hline $1.2,3,7,8,9-\mathrm{HxD}$ & 0.25 & 0.1 & 0.3 & 0.2 & 0.2 & 0.2 & 0.15 & 0.35 & n.a. & 0.04 & 1.a. \\
\hline non- $2,3,7,8-\mathrm{HxD}$ & 0.45 & 0.15 & n.a. & n.a. & n.a. & n.a. & n.a. & n.a. & n.a. & 0.1 & n.a. \\
\hline $1.2 .3 .4 .6 .7,8-\mathrm{HpF}$ & 0.15 & 0.4 & 0.3 & 0.1 & 0.7 & 0.1 & 0.4 & 0.2 & n.a. & 0.05 & n.a. \\
\hline $1,2,3,4,7,8,9-\mathrm{HpF}$ & 0.3 & 0.05 & 0.05 & 0.05 & 0.15 & 0.05 & 0.05 & 0.1 & n.a. & 0.035 & n.a. \\
\hline non-2,3,7,8-HpF & 0.5 & 0.36 & n.a. & n.a. & n.a. & n.a. & n.a. & n.a. & n.a. & 0.2 & n.a. \\
\hline $1,2,3,4,6,7,8-H p D$ & 0.3 & 0.99 & 3.3 & 3 & 4.5 & 1.6 & 2 & 3.5 & n.a. & 0.15 & n.a. \\
\hline non-2,3,7,8-HpF & 0.5 & 0.85 & n.a. & n.a. & n.a. & n.a. & n.a. & n.a. & n.a. & 0.5 & n.a. \\
\hline OCDF & 0.5 & 0.54 & 2.5 & 2.1 & 0.5 & 1.05 & 2.9 & 2.1 & n.a. & 0.15 & n.a. \\
\hline \multirow[t]{2}{*}{ OCDD } & 1.5 & 4 & 14.6 & 15 & 7.1 & 7.5 & 15.8 & 15 & n.a. & 0.5 & n.a. \\
\hline & SRWD & E174/1 & E168/1 & E198 & G151 & G101 & E197 & & E208 & $\mathrm{G} 103$ & Gl11 \\
\hline$-\mathrm{TeF}$ & n.a. & 0.25 & 0. & 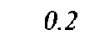 & 0 & 0. & 0.15 & & 0.15 & 0.1 & 0.04 \\
\hline non-2,3,7,8-TeF & n.a. & 0.6 & 0.75 & 0.76 & 1.04 & 6.56 & 0.44 & & 0.15 & 0.3 & 0.1 \\
\hline 2,3,7,8-TeD & n.a. & 0.1 & 0.05 & 0.045 & 0.04 & 0.05 & 0.05 & & 0.1 & 0.1 & 0.05 \\
\hline non-2,3,7,8-TeD & n.a. & 0.1 & 0.05 & 0.045 & 0.1 & 0.05 & 0.05 & & 0.1 & 0.1 & 0.05 \\
\hline $1,2,3,7,8-\mathrm{PeF}$ & n.a. & 0.05 & 0.1 & 0.2 & 0.1 & 0.35 & 0.16 & & 0.05 & 0.05 & 0.05 \\
\hline 2,3 & n.a. & 0.15 & 0.1 & 0.38 & 0.15 & 0.2 & 0.15 & & 0.15 & 0.05 & 0.1 \\
\hline non-2,3,7,8-PeF & n.a. & 0.15 & 0.15 & 0.88 & 0.25 & 4.52 & 0.15 & & 0.25 & 0.25 & 0.1 \\
\hline $1,2,3,7,8-\mathrm{PeD}$ & n.a. & 0.1 & 0.05 & 0.1 & 0.1 & 0.49 & 0.1 & & 0.1 & 0.1 & 0.1 \\
\hline non- $2,3,7,8-\mathrm{PeD}$ & n.a. & 0.1 & 0.05 & 0.1 & 0.1 & 0.2 & 0.1 & & 0.1 & 0.2 & 0.1 \\
\hline $1,2,3,4,7,8-\mathrm{HxF}$ & n.a. & 0.1 & 0.1 & 0.1 & 0.15 & 0.2 & 0.1 & & 0.05 & 0.15 & 0.05 \\
\hline $1,2,3,6,7,8-\mathrm{HxF}$ & n.a. & 0.1 & 0.1 & 0.045 & 0.1 & 0.35 & 0.1 & & 0.1 & 0.2 & 0.05 \\
\hline $2,3,4,6,7,8-\mathrm{HxF}$ & n.a. & 0.15 & 0.1 & 0.22 & 0.15 & 0.2 & 0.1 & & 0.1 & 0.2 & 0.05 \\
\hline $1,2,3,7,8,9-\mathrm{HxF}$ & n.a. & 0.05 & 0.045 & 0.04 & 0.1 & 0.1 & 0.04 & & 0.15 & 0.15 & 0.15 \\
\hline non- $2,3,7,8-\mathrm{HxF}$ & n.a. & $a$. & 0. & 0.15 & 0.3 & 8 & 0.83 & & 0.05 & 0.5 & 0.05 \\
\hline 1,2 , & n.a. & a & 0.05 & 0.05 & 0.1 & 0.1 & 0.03 & & 0.1 & 0.15 & 0.1 \\
\hline $1,2,3,6,7,8-\mathrm{HxD}$ & n.a. & 0.2 & 0.15 & 0.05 & 0.3 & 0.25 & 0.1 & & 0.15 & 0.25 & 0.1 \\
\hline $1,2,3,7,8,9-\mathrm{HxD}$ & n.a. & 0.1 & 0.1 & 0.045 & 0.1 & 0.2 & 0.03 & & 0.1 & 0.15 & 0.1 \\
\hline non- $2,3,7,8-\mathrm{HxD}$ & n.a. & 0.15 & 0.1 & 0.1 & 0.3 & 0.35 & 0.1 & & 0.1 & 0.4 & 0.1 \\
\hline $1,2,3,4,6,7,8-\mathrm{HpF}$ & n.a. & 0.15 & 0.2 & 0.16 & 0.15 & 0.1 & 0.1 & & 0.15 & 1.04 & 0.1 \\
\hline $1,2,3,4,7,8,9-\mathrm{HpF}$ & n.a. & 0.05 & 0.03 & 0.04 & 0.05 & 0.03 & 0.03 & & 0.15 & 0.15 & 0.15 \\
\hline non- $2,3,7,8-\mathrm{HpF}$ & n.a. & 0.1 & 0.1 & 0.09 & 0.1 & 2.6 & 0.1 & & 0.15 & 2.29 & 0.1 \\
\hline $1,2,3,4,6,7,8-\mathrm{HpD}$ & n.a. & 0.4 & 0.4 & 0.35 & 0.88 & 0.3 & 0.4 & & 0.35 & 2.34 & 0.25 \\
\hline non- $2,3,7,8-\mathrm{HpF}$ & n.a. & 0.25 & 0.2 & 0.2 & 0.5 & 0.1 & 0.2 & & 0.15 & 1.87 & 0.25 \\
\hline $\mathrm{OCDF}$ & n.a. & 0.46 & 0.27 & 0.15 & 0.15 & 0.15 & 0.36 & & 0.35 & 6.25 & 0.4 \\
\hline OCDD & n.a. & 5.32 & 4.59 & 3.96 & 4.7 & 3.66 & 5.33 & & 1 & 27.7 & 2 \\
\hline
\end{tabular}

